\title{
VASCULAR OXIDATIVE STRESS IN ALZHEIMER DISEASE
}

\author{
Xiongwei Zhu ${ }^{1}$, Mark A. Smith ${ }^{1}$, Kazuhiro Honda ${ }^{2}$, Gjumrakch Aliev ${ }^{1}$, Paula I. Moreira ${ }^{3}$, \\ Akihiko Nunomura $^{4}$, Gemma Casadesus ${ }^{1}$, Peggy L.R. Harris ${ }^{1}$, Sandra L. Siedlak ${ }^{1}$, and \\ George Perry ${ }^{1,5}$ \\ 1 Department of Pathology, Case Western Reserve University, Cleveland, Ohio 44106, USA
}

2 Department of Internal Medicine, Shinmatsudo Central General Hospital, Chiba 270-0034, Japan

3 Center for Neuroscience and Cell Biology of Coimbra, University of Coimbra, 3004-517 Coimbra, Portugal

4 Department of Psychiatry and Neurology, Asahikawa Medical College, Asahikawa 078-8510, Japan

5 College of Sciences, University of Texas at San Antonio, San Antonio, Texas 78249-0661, USA

\begin{abstract}
Alzheimer disease and cerebrovascular dementia are two common causes of dementia and, by present diagnostic criteria, are mutually exclusive using vascular pathology as an arbitrary demarcation in differential diagnosis. However, evidence from epidemiological, neuropathological, clinical, pharmacological, and functional studies suggest considerable overlap in risk factors and pathological changes suggesting shared common pathogenic mechanisms between these two diseases such that vascular factors play a vital role in the pathogenesis of Alzheimer disease. A high energy demand and lack of an endogenous fuel reserve make the brain highly dependent upon a continuous blood supply where disruption of cerebral blood vessels and blood flow can have serious consequences on neural activities. Indeed, many studies implicate metabolic defects in Alzheimer disease, such a reduced brain metabolism is one of the best documented abnormalities in the disease. Notably, since endothelial reactive oxygen species such as nitric oxide act as vasodilators at low concentrations, increased production coupled with elevated reactive oxygen species scavenging of nitric oxide, can lead to reduced bioavailability of nitric oxide and increased oxidative stress that damage sensitive vascular cells. In this respect, we and others have demonstrated that oxidative stress is one of the earliest pathological changes in the brain of Alzheimer disease patients and plays a critical role in the vascular abnormalities underlying metabolic defects in Alzheimer disease. Here, we discuss vascular factors in relation to Alzheimer disease and review hypoperfusion as a potential cause by triggering mitochondrial dysfunction and increased oxidative stress initiating the pathogenic process.
\end{abstract}

\section{Keywords}

Alzheimer disease; hypoperfusion; mitochondria; nitric oxide; nitric oxide synthase; oxidative stress; vascular abnormalities

Correspondence to: George Perry, Ph.D., College of Sciences, University of Texas at San Antonio, 6900 North Loop 1604 West, San Antonio, Texas 78249-0661 USA, Tel: 210-458-4450, Fax: 210-458-4445, george.perry@utsa.edu.

Publisher's Disclaimer: This is a PDF file of an unedited manuscript that has been accepted for publication. As a service to our customers we are providing this early version of the manuscript. The manuscript will undergo copyediting, typesetting, and review of the resulting proof before it is published in its final citable form. Please note that during the production process errors may be discovered which could affect the content, and all legal disclaimers that apply to the journal pertain. 


\section{Vascular Abnormalities in Alzheimer disease}

Cerebrovascular function declines with aging as evidenced by declines in cerebral blood flow (CBF), loss of endothelial mitochondria, a thickening of the vascular basement membrane, and an increase in degenerative pericytes in the elderly [1]. A more pronounced decline is present in cases of Alzheimer disease (AD) with: reduction in number of cerebral microvessels, significant aberrations in capillary walls including decreased capillary diameters and increased capillary densities [2,3], agrin deposition in capillaries suggestive of the thinning and fragmentation of the basal lamina [4], atrophy of smooth muscle cells in cerebral vessels and attenuation of capillary endothelium resulting in the rupture of the vessel wall and intracerebral bleeding [5]. Resting CBF is reduced and the increase in CBF stimulated by neural activity is attenuated [6] and several factors that may ameliorate $\mathrm{AD}$ have either been associated with improved CBF or prevent CBF decline [7]. Several morphometric features of blood brain barrier (BBB) dysfunction in patient with pathologically confirmed AD have also been reported [8]. The association of serum amyloid $\mathrm{P}$ component, a protein not synthesized in the brain, with senile plaques and neurofibrillary tangles (NFT), supports the notion of BBB leakage in $\mathrm{AD}$ [9]. Amyloid- $\beta(\mathrm{A} \beta)$ deposits, one of the prominent features of $\mathrm{AD}$, are found in cortical and subcortical gray matter and in meningeal and gray matter blood vessels [10,11], and the source of this $A \beta$ is likely vascular endothelial cells and smooth muscle cells rather than neurons since endothelial cells and smooth muscle cells show abundant amyloid- $\beta$ protein precursor (A $\beta \mathrm{PP}$ ) immunoreactivity $[12,13]$. The frequent deposition of $\mathrm{A} \beta$ in arteriolar media and collagen deposition in the adventitia in AD may cause a narrowing of the lumen of cerebrovessels, even in the absence of overt endothelial injury, not mentioning the vasoconstriction effect of soluble $A \beta$ [14]. Therefore, perivascular $A \beta$ deposits may be a risk factor for reduced regional CBF [7]. Ultrastructural studies on blood vessels associated with $\mathrm{A} \beta$ deposits have shown their intermittent association with membrane abnormalities of smooth muscle cells [5]. Indeed, in AD cases with a clinical history of cerebral bleeding, the muscle layer is sometimes completely replaced by $\mathrm{A} \beta$ deposits, suggesting that the vascular system may be an initiator for the development of disease $[12,13]$. That said, the contribution of amyloid angiopathy in cases that do not progress to $\mathrm{AD}$ is less clear.

\section{Vascular Oxidative Stress in Alzheimer Disease}

Reactive oxygen species (ROS) are generated at sites of injury and/or inflammation. At low levels, ROS can function as signaling intermediates in the regulation of fundamental cell activities such as growth and adaptation responses, however, at higher concentrations, ROS cause cell injury and death. The vascular endothelium, neurons and glia are all able to synthesize, store and release ROS and vasoactive substances in response to certain stimuli, especially those by chronic hypoxia/hypoperfusion. The vascular endothelium, which regulates the passage of macromolecules and circulating cells from blood to tissue, is a major target of oxidant stress, playing a critical role in the pathophysiology of several vascular diseases [15, 16]. Specifically, accumulated oxidative stress: 1) interferes with nitric oxide (NO) function and endothelial relaxation; 2 ) increases vascular endothelial permeability and promotes leukocyte adhesions; 3 ) leads to alterations in endothelial signal transduction, redox-regulated transcription factors and reduced CBF [16].

It is well-characterized that there are increased regional levels of oxidative stress in the AD brain $[17,18]$. For example, recent studies have demonstrated a decline in polyunsaturated fatty acids (PUFA) [19,20], increased levels of lipid peroxidation markers [19,21,22], as well as protein oxidation [23,24], DNA oxidation [25-27] and RNA oxidation [28-31] during AD. Additionally, the presence of oxidative stress markers such as advanced glycation end products (AGE), glycoxidative end products, e.g., $\mathrm{N}^{\varepsilon}$-carboxymethyllysine and lipid peroxidation adducts are detected in both NFT and senile plaques in AD [21-24,32-35]). Notably, similar 
increases in oxidative stress also occur systemically in AD. Lower plasma antioxidant levels and alterations in antioxidant enzyme activities are reported in mild cognitive impairment (MCI) patients and patients at early AD stages [19,36-39] suggesting a systemic imbalance between ROS production and antioxidant defense systems in the plasma of AD patients and this is substantiated by increases in DNA, lipid, and protein oxidation products found in blood and cerebrospinal fluid (CSF) obtained from AD patients in comparison with controls [35, 40,41]. Reflecting such a systemic oxidative imbalance in $\mathrm{AD}$, we also found oxidative damage in olfactory neurons and the surrounding epithelial cells from AD donors [42], and another group reported increased 8-hydroxy-deoxyguanosine (8OHdG) in the DNA of lymphocytes from AD donors [43], which inversely correlated with the plasma levels of several antioxidant carotenoids [44].

Interestingly, our recent finding demonstrated ultrastructural features of vascular lesions and mitochondria in brain vascular wall cells from human AD brain biopsy are also suggestive of oxidative damage [45,46]. In situ hybridization using mitochondrial DNA (mtDNA) probes for human wild type, $5 \mathrm{~kb}$ deleted and mouse mtDNA and immunocytochemistry using antibodies against A $\beta \mathrm{PP}, 8$-hydroxy-2'-guanosine (8OHG) and cytochrome $\mathrm{C}$ oxidase subunit $1(\mathrm{COX})$ revealed similar ultrastructural localization [45,46]. As expected, there was a higher degree of amyloid deposition in the vascular walls in $\mathrm{AD}$ compared to aged-matched controls $[45,46]$ and in addition, vessels with more severe lesions showed immunopositive staining for $\mathrm{A} \beta \mathrm{PP}$ and contained large, lipid-laden vacuoles in the cytoplasm of endothelial cells. Significantly more mitochondria abnormalities were seen in microvessels where lesions occurred [45,46]. In situ hybridization using wild and chimera $(5 \mathrm{kB}) \mathrm{mtDNA}$ probes revealed positive signals in severely damaged mitochondria from the vascular endothelium and in the perivascular cells of lesioned microvessels close to regions of large amyloid deposition. These features were absent in undamaged regions of human AD tissues or in age-matched control subjects. Importantly, vessels with atherosclerotic lesions revealed endothelium and perivascular cells possessing clusters of wild and deleted mtDNA-containing positive probes that were associated with increased amounts of immunoreactive A $\beta \mathrm{PP}, 8 \mathrm{OHG}$ and COX in the same cellular compartment $[45,46]$. Our observations demonstrate that vascular wall cells, especially their mitochondria, appear to be a central target for oxidative stress-induced damage before the development of AD pathology [45,46]. Notably, long-term ischemia/reperfusion leads to disintegration of mitochondria ultrastructure [47,48] and apoptosis of degenerating neurons occurs in association with the accumulation of perikaryal abnormal mitochondria and oxidative damage to the nucleus [49]. Likely not coincidentally, this same pattern of mitochondria lesions is observed in human AD brain biopsy samples [50].

\section{Nitric Oxide Malfunction and Vascular Oxidative Stress in Alzheimer Disease}

The vascular endothelial cells transduce circulatory stimuli to the arterial wall leading to the regulation of vascular tone, haemostasis, blood pressure and vascular remodeling through the synthesis and release of vasoactive NO [51,52]. NO is synthesized by the conversion of Larginine to L-citrulline by the enzyme of nitric oxide synthase (NOS) which exists in three isoforms in brain: eNOS localized in endothelial cells; nNOS localized in neurons; and inducible NOS (iNOS) induced in neurons and glial cells after cytokine activation [51,52]. Due to its vascular effect, $\mathrm{NO}$, at physiological level, improves tissue perfusion and exert a protective action and reduced bioavailability of $\mathrm{NO}$ is thought to be one of the central factors common to vascular diseases. However, overproduction, either by activation of $\mathrm{nNOS}$ by excitatory [53], or by induction of iNOS in glial, vascular or blood cells [54-56] might be deleterious, which is especially true if combined with concurrent increases in free radical production. For example, excess NO production is found during excitotoxicity, inflammation and ischemia reperfusion injury [57] and it is known that $\mathrm{NO}$ can react with superoxide and the reaction is approximately six-times faster than the dismutation of superoxide by superoxide 
dismutase (SOD) [58]. Therefore, if the levels of NO or superoxide increase sufficiently, NO is able to outcompete SOD which leads to dual effects of scavenging NO and thereby actually reducing its bioavailability (ROS scavenging), but also of producing the potent oxidant peroxynitrite. Once formed, peroxynitrite can nitrate tyrosine residues to form nitrotyrosine. Additionally, substantial amounts of ONOO- can be protonated at physiological $\mathrm{pH}$ to form peroxynitrous acid, a strong oxidant itself, which in turn can yield the highly reactive $\mathrm{OH} \bullet$, a much more powerful oxidant that will readily react with any biological molecules it meets [51,52].

Increased nitrotyrosine is found in astrocytes, blood vessels and the neuronal cytoplasm of the cerebral cortex within regions of neurodegeneration in $\mathrm{AD}$, yet it is undetectable in corresponding control regions $[24,59,60]$. There is also a significant two- to three-fold increase in the lipid nitration product, 5-nitro- $\gamma$-tocopherol, in affected regions of the brain in AD, suggesting NO is a significant contributor to lipid oxidation [61]. The widespread occurrence of nitrotyrosine immunoreactivity $[24,59,60]$ suggests that chronic oxidative damage is not restricted to long-lived polymers such as NFTs, but instead, reflects a generalized oxidative stress contributing to the pathogenesis of $\mathrm{AD}$. Consistent with these observations, aberrant expression of all isoforms of NOS and some related proteins is observed in AD.

Dimethylargininase, primarily expressed in tissues containing the constitutive forms of NOS, like brain, kidney, and endothelium [62,63], regulates NO production by hydrolyzing free methylated arginine derivatives (effective endogenous inhibitors of NOS) [64]. The expression of dimethylargininase is dramatically increased in $\mathrm{AD}$ [65]. However, there are controversial reports regarding asymmetric dimethylarginine levels in $\mathrm{AD}[66,67]$. The mRNA and protein levels of the enzyme argininosuccinate synthetase, the rate limiting enzyme in the metabolic pathway leading from L-citrulline to L-arginine (the physiological substrates of NOS), are significantly higher in glial cells of AD brain [68,69]. Metabolism of tetrahydrobiopterin $\left(\mathrm{BH}_{4}\right)$, an essential cofactor for NOS, is disturbed in AD patients [70,71], which will lead to the "uncoupling" of NOS favoring the production of superoxide anion and hydrogen peroxide [72]. Large and small mutipolar and pyramidal neurons demonstrate increased nNOS levels over the entire chronic AD evolution [72,73]. eNOS levels are also increased in AD brain and colocalize with nitrotyrosine $[59,60]$. The expression of iNOS is found in a variety of cells in response to lipopolysaccharides, certain cytokines and ROS generators [74]. Because iNOS produces much greater amounts of NO than either eNOS or nNOS [75], it is an important mediator of cytotoxicity in the brain. It is consistently reported by various groups that there is increased iNOS in glial cells and a subset of pyramidal neurons in AD [59,68,69,76-78]. Colocalization of argininosuccinate synthetase and iNOS is detectable in these cells, coupled with increased expression levels, suggesting high output of NO production [69] Genetic ablation of iNOS substantially protects AD-transgenic mice from premature mortality, cerebral plaque formation, amyloid-load, protein tyrosine nitration, astrocytosis and microgliosis [79]. Despite the consistent evidence of increased NOS expression in AD, the steady level of NO in the plasma of $\mathrm{AD}$ patient is actually decreased, suggestive of reduced bioavailability of NO underlying reduced cerebral blood flow [66]. Given that protein nitration is a non-crosslinkrelated oxidative modification which indicates more recent active modifications, the widespread nitrative modifications and decreased steady level of NO in AD actually highlights a critical pathogenic role of increased production coupled with elevated ROS scavenging of $\mathrm{NO}$ which leads to a net outcome of reduced bioavailability of $\mathrm{NO}$ and increased oxidative stress.

\section{Vascular Risk Factors, Vascular Oxidative Stress and Alzheimer Disease}

There are many common underlying risk factors that play key roles in the development of vascular diseases and $\mathrm{AD}$ including the presence of apolipoprotein E4 (ApoE) allele, hyperhomocysteinemia, diabetes mellitus, atherosclerosis and hypertention [80]. Almost all of 
these factors are associated with vascular oxidative stress and/or vascular NO malfunction. For example, there is an isoform specific difference for ApoE in microglial NO production [8183]: Mice expressing the ApoE4 protein isoform have a greater NO production than mice expressing the ApoE3 protein isoform and both neurons and microphages from ApoE4 transgenic mice exhibit a similar increase in the uptake of arginine, the sole substrate for NOS, over that from ApoE4 mice. Elevated cerebral oxidative stress has been observed in AD individuals carrying the $\varepsilon 4$ alleles. Diabetes mellitus also appear to cause NO malfunction at least partly through enhancement of oxidative stress: advanced glycation products, accumulated in diabetic tissues [84], are toxic to endothelial cells which may lead to uncoupling of endothelial NO synthase such that it generates superoxide anion in addition to NO. Also, hyperglycemia and hyperinsulinemia increase both superoxide and hydrogen peroxide production $[85,86]$ that enhances ROS scavenging of NO. Similarly, hyperhomocysteinemia can elicit mitochondrial damage that leads to increased ROS production as well as directly scavenge NO by forming S-nitrosohomocysteine [87].

\section{Potential Sources of Vascular Oxidative Stress in Alzheimer Disease}

The enzymatic origin of superoxide could potentially involve $\mathrm{NAD}(\mathrm{P}) \mathrm{H}$ oxidase, xanthine oxidase, lipoxygenase, NOS and also respiratory chain enzymes in the mitochondria, which all demonstrate alterations in $\mathrm{AD}$. $\mathrm{NAD}(\mathrm{P}) \mathrm{H}$ oxidases are implicated in vascular oxidative stress associated with various vascular conditions such as hypertension and hyperhomocysteinemia and NADPH oxidase is significantly activated in AD brain [88]. Lipoxygenase enzymes by oxidizing polyunsaturated fatty acids synthesize hydroperoxyacids, which are potent pro-oxidant mediators [89,90]. Levels of 12/15 lipoxygenase as well as their metabolic products are significantly elevated in AD brain [88]. Mitochondrial dysfunction is a key step in AD progression. Damaged mitochondria are less efficient producers of ATP but more efficient producers of ROS. There is ample evidence suggesting mitochondrial abnormalities in $\mathrm{AD}$ brain as discussed earlier [91].

\section{Hypoperfusion as a Potential Cause of Alzheimer Disease}

Neuroimaging studies supports the notion that in MCI patients who later converted to AD, the presence of temporoparietal (including hippocampal) hypoperfusion, hippocampalparahippocampal hypoperfusion, and posteriorcingulate hypoperfusion distinguish this population group from other groups suggesting that hypoperfusion is a very early feature during the development of AD [92-97]. Similarly, there are profound alterations in the regulation of the cerebral circulation in A $\beta \mathrm{PP}$ transgenic mice at a very early age which is well before other pathological changes [98]. It is likely that hypoperfusion plays a critical role in the pathogenesis of AD. de la Torre [99] proposed that advanced aging with a comorbid condition, such as a vascular risk factor, which further decreases cerebral perfusion, promotes a critically attained threshold of cerebral hypoperfusion (CATCH). Clearly, mitochondria in vulnerable cells almost always show signs of damage during ischemia [100]. Importantly, chronic reductions in cerebral flow of a magnitude thought to be harmless to neurons (i.e., reduced by $25 \sim 50 \%$ ) induced disorganization of the CA1 sector where neurons demonstrate increased lipofuscin pigments, suggestive of mitochondrial abnormalities [101]. Therefore, it is likely that chronic hypoperfusion will trigger mitochondrial damage/dysfunction in vascular cells which, in turn, will enhance the production of ROS. The accumulation of ROS scavenges NO, impairs endothelial barrier function and promotes leukocyte adhesion, induces alterations in normal vascular function and results in further decreased CBF. Because glucose is the main fuel of brain cells, suboptimal delivery of energy substrates to neuronal tissue due to decreased CBF, together with a deficient delivery of oxygen, compromises neuronal stability because the supply for aerobic glycolysis fails to meet brain tissue demand and hypometablism ensues. Clearance of $\mathrm{A} \beta$ through the vascular pathway is likely also impaired that may lead to its 
deposition in the brain parenchyma. Sustained hypoperfusion, and then oxidative stress of brain tissues, could also stimulate secondary damage via the overexpression of inducible and neuronal specific nitric oxide synthase (NOS: iNOS and nNOS, respectively) in brain cells. It is possible that continuous accumulation of oxidative stress products, such as peroxynitrite accumulation (via the overexpression of the iNOS and/or nNOS), appear to be secondary and accelerating factors for damage and for compromising the blood brain barrier (BBB) in hypoxia/hypoperfusion or AD. All of these alterations probably contribute to the progressive cognitive decline characteristic of patients with $\mathrm{AD}$, and regional anatomic pathology, consisting of synaptic loss, senile plaques, and NFT.

\section{Conclusions}

Vascular cells are sensitive to oxidative stress and it is likely that oxidative stress plays a critical role leading to vascular abnormalities in $\mathrm{AD}$. We suspect that chronic vascular hypoperfusion is a central initiating factor for vascular alterations by inducing mitochondrial dysfunction, increasing ROS production, reducing NO bioavailability via ROS scavenging, and damaging vascular functions as well as severely affecting regional $\mathrm{CBF}$ which ultimately leading to cognition decline and the disease.

\section{Acknowledgements}

Work in the authors' laboratories is supported by the National Institutes of Health, the Alzheimer's Association, Philip Morris USA Inc. and Philip Morris International.

\section{References}

1. Bostrom K, Hassler O. A pilot microradiological investigation on the occurrence of calcifications in various arteries of the human body. J Gerontol 1966;21:97-102. [PubMed: 5901663]

2. Bell MA, Ball MJ. Morphometric comparison of hippocampal microvasculature in ageing and demented people: diameters and densities. Acta Neuropathol (Berl) 1981;53:299-318. [PubMed: 7223373]

3. Mancardi GL, Perdelli F, Rivano C, Leonardi A, Bugiani O. Thickening of the basement membrane of cortical capillaries in Alzheimer's disease. Acta Neuropathol (Berl) 1980;49:79-83. [PubMed: 7355675]

4. Donahue JE, Berzin TM, Rafii MS, Glass DJ, Yancopoulos GD, Fallon JR, Stopa EG. Agrin in Alzheimer's disease: altered solubility and abnormal distribution within microvasculature and brain parenchyma. Proc Natl Acad Sci U S A 1999;96:6468-72. [PubMed: 10339611]

5. Perry G, Smith MA, McCann CE, Siedlak SL, Jones PK, Friedland RP. Cerebrovascular muscle atrophy is a feature of Alzheimer's disease. Brain Res 1998;791:63-6. [PubMed: 9593825]

6. Iadecola C. Neurovascular regulation in the normal brain and in Alzheimer's disease. Nat Rev Neurosci 2004;5:347-60. [PubMed: 15100718]

7. Crawford JG. Alzheimer's disease risk factors as related to cerebral blood flow: additional evidence. Med Hypotheses 1998;50:25-36. [PubMed: 9488178]

8. Stewart PA, Hayakawa K, Akers MA, Vinters HV. A morphometric study of the blood-brain barrier in Alzheimer's disease. Lab Invest 1992;67:734-42. [PubMed: 1460864]

9. Hachinski V, Munoz DG. Cerebrovascular pathology in Alzheimer's disease: cause, effect or epiphenomenon? Ann N Y Acad Sci 1997;826:1-6. [PubMed: 9329676]

10. Kalaria RN. The blood-brain barrier and cerebrovascular pathology in Alzheimer's disease. Ann N Y Acad Sci 1999;893:113-25. [PubMed: 10672233]

11. Kalaria RN. The role of cerebral ischemia in Alzheimer's disease. Neurobiol Aging 2000;21:32130. [PubMed: 10867217]

12. Kawai M, Kalaria RN, Harik SI, Perry G. The relationship of amyloid plaques to cerebral capillaries in Alzheimer's disease. Am J Pathol 1990;137:1435-46. [PubMed: 2260630] 
13. Tagliavini F, Ghiso J, Timmers WF, Giaccone G, Bugiani O, Frangione B. Coexistence of Alzheimer's amyloid precursor protein and amyloid protein in cerebral vessel walls. Lab Invest 1990;62:761-7. [PubMed: 2113597]

14. Suo Z, Su G, Placzek A, Kundtz A, Humphrey J, Crawford F, Mullan M. A beta vasoactivity in vivo. Ann N Y Acad Sci 2000;903:156-63. [PubMed: 10818502]

15. Faraci FM, Heistad DD. Regulation of the cerebral circulation: role of endothelium and potassium channels. Physiol Rev 1998;78:53-97. [PubMed: 9457169]

16. Lum H, Roebuck KA. Oxidant stress and endothelial cell dysfunction. Am J Physiol Cell Physiol 2001;280:C719-41. [PubMed: 11245588]

17. Zhu X, Lee HG, Casadesus G, Avila J, Drew K, Perry G, Smith MA. Oxidative imbalance in Alzheimer's disease. Mol Neurobiol 2005;31:205-17. [PubMed: 15953822]

18. Zhu X, Raina AK, Lee HG, Casadesus G, Smith MA, Perry G. Oxidative stress signalling in Alzheimer's disease. Brain Res 2004;1000:32-9. [PubMed: 15053949]

19. Lovell MA, Xie C, Markesbery WR. Decreased glutathione transferase activity in brain and ventricular fluid in Alzheimer's disease. Neurology 1998;51:1562-6. [PubMed: 9855502]

20. Prasad MR, Lovell MA, Yatin M, Dhillon H, Markesbery WR. Regional membrane phospholipid alterations in Alzheimer's disease. Neurochem Res 1998;23:81-8. [PubMed: 9482271]

21. Smith MA, Perry G, Richey PL, Sayre LM, Anderson VE, Beal MF, Kowall N. Oxidative damage in Alzheimer's. Nature 1996;382:120-1. [PubMed: 8700201]

22. Sayre LM, Zelasko DA, Harris PL, Perry G, Salomon RG, Smith MA. 4-Hydroxynonenal-derived advanced lipid peroxidation end products are increased in Alzheimer's disease. J Neurochem 1997;68:2092-7. [PubMed: 9109537]

23. Smith MA, Rudnicka-Nawrot M, Richey PL, Praprotnik D, Mulvihill P, Miller CA, Sayre LM, Perry G. Carbonyl-related posttranslational modification of neurofilament protein in the neurofibrillary pathology of Alzheimer's disease. J Neurochem 1995;64:2660-6. [PubMed: 7539057]

24. Smith MA, Richey Harris PL, Sayre LM, Beckman JS, Perry G. Widespread peroxynitrite-mediated damage in Alzheimer's disease. J Neurosci 1997;17:2653-7. [PubMed: 9092586]

25. Mecocci P, MacGarvey U, Kaufman AE, Koontz D, Shoffner JM, Wallace DC, Beal MF. Oxidative damage to mitochondrial DNA shows marked age-dependent increases in human brain. Ann Neurol 1993;34:609-16. [PubMed: 8215249]

26. Mecocci P, MacGarvey U, Beal MF. Oxidative damage to mitochondrial DNA is increased in Alzheimer's disease. Ann Neurol 1994;36:747-51. [PubMed: 7979220]

27. Mecocci P, Beal MF, Cecchetti R, Polidori MC, Cherubini A, Chionne F, Avellini L, Romano G, Senin U. Mitochondrial membrane fluidity and oxidative damage to mitochondrial DNA in aged and AD human brain. Mol Chem Neuropathol 1997;31:53-64. [PubMed: 9271005]

28. Nunomura A, Perry G, Pappolla MA, Wade R, Hirai K, Chiba S, Smith MA. RNA oxidation is a prominent feature of vulnerable neurons in Alzheimer's disease. J Neurosci 1999;19:1959-64. [PubMed: 10066249]

29. Nunomura A, Chiba S, Lippa CF, Cras P, Kalaria RN, Takeda A, Honda K, Smith MA, Perry G. Neuronal RNA oxidation is a prominent feature of familial Alzheimer's disease. Neurobiol Dis 2004;17:108-13. [PubMed: 15350971]

30. Nunomura A, Perry G, Pappolla MA, Friedland RP, Hirai K, Chiba S, Smith MA. Neuronal oxidative stress precedes amyloid-beta deposition in Down syndrome. J Neuropathol Exp Neurol 2000;59:1011-7. [PubMed: 11089579]

31. Nunomura A, Perry G, Aliev G, Hirai K, Takeda A, Balraj EK, Jones PK, Ghanbari H, Wataya T, Shimohama S, Chiba S, Atwood CS, Petersen RB, Smith MA. Oxidative damage is the earliest event in Alzheimer disease. J Neuropathol Exp Neurol 2001;60:759-67. [PubMed: 11487050]

32. Smith MA, Taneda S, Richey PL, Miyata S, Yan SD, Stern D, Sayre LM, Monnier VM, Perry G. Advanced Maillard reaction end products are associated with Alzheimer disease pathology. Proc Natl Acad Sci U S A 1994;91:5710-4. [PubMed: 8202552]

33. Smith MA, Richey PL, Taneda S, Kutty RK, Sayre LM, Monnier VM, Perry G. Advanced Maillard reaction end products, free radicals, and protein oxidation in Alzheimer's disease. Ann N Y Acad Sci 1994;738:447-54. [PubMed: 7832455] 
34. Markesbery WR, Lovell MA. Four-hydroxynonenal, a product of lipid peroxidation, is increased in the brain in Alzheimer's disease. Neurobiol Aging 1998;19:33-6. [PubMed: 9562500]

35. Markesbery WR, Carney JM. Oxidative alterations in Alzheimer's disease. Brain Pathol 1999;9:13346. [PubMed: 9989456]

36. Rottkamp CA, Nunomura A, Raina AK, Sayre LM, Perry G, Smith MA. Oxidative stress, antioxidants, and Alzheimer disease. Alzheimer Dis Assoc Disord 2000;14(Suppl 1):S62-6. [PubMed: 10850732]

37. Rinaldi P, Polidori MC, Metastasio A, Mariani E, Mattioli P, Cherubini A, Catani M, Cecchetti R, Senin U, Mecocci P. Plasma antioxidants are similarly depleted in mild cognitive impairment and in Alzheimer's disease. Neurobiol Aging 2003;24:915-9. [PubMed: 12928050]

38. Riviere S, Birlouez-Aragon I, Nourhashemi F, Vellas B. Low plasma vitamin C in Alzheimer patients despite an adequate diet. Int J Geriatr Psychiatry 1998;13:749-54. [PubMed: 9850871]

39. Bourdel-Marchasson I, Delmas-Beauvieux MC, Peuchant E, Richard-Harston S, Decamps A, Reignier B, Emeriau JP, Rainfray M. Antioxidant defences and oxidative stress markers in erythrocytes and plasma from normally nourished elderly Alzheimer patients. Age Ageing 2001;30:235-41. [PubMed: 11443025]

40. Riviere S, Birlouez-Aragon I, Vellas B. Plasma protein glycation in Alzheimer's disease. Glycoconj J 1998;15:1039-42. [PubMed: 10211709]

41. Pratico D. Alzheimer's disease and oxygen radicals: new insights. Biochem Pharmacol 2002;63:5637. [PubMed: 11992623]

42. Perry G, Castellani RJ, Smith MA, Harris PL, Kubat Z, Ghanbari K, Jones PK, Cordone G, Tabaton M, Wolozin B, Ghanbari H. Oxidative damage in the olfactory system in Alzheimer's disease. Acta Neuropathol (Berl) 2003;106:552-6. [PubMed: 12955399]

43. Mecocci P, Polidori MC, Ingegni T, Cherubini A, Chionne F, Cecchetti R, Senin U. Oxidative damage to DNA in lymphocytes from AD patients. Neurology 1998;51:1014-7. [PubMed: 9781522]

44. Mecocci P, Polidori MC, Cherubini A, Ingegni T, Mattioli P, Catani M, Rinaldi P, Cecchetti R, Stahl W, Senin U, Beal MF. Lymphocyte oxidative DNA damage and plasma antioxidants in Alzheimer disease. Arch Neurol 2002;59:794-8. [PubMed: 12020262]

45. Aliev G, Seyidova D, Neal ML, Shi J, Lamb BT, Siedlak SL, Vinters HV, Head E, Perry G, Lamanna JC, Friedland RP, Cotman CW. Atherosclerotic lesions and mitochondria DNA deletions in brain microvessels as a central target for the development of human AD and AD-like pathology in aged transgenic mice. Ann N Y Acad Sci 2002;977:45-64. [PubMed: 12480733]

46. Aliyev A, Chen SG, Seyidova D, Smith MA, Perry G, de la Torre J, Aliev G. Mitochondria DNA deletions in atherosclerotic hypoperfused brain microvessels as a primary target for the development of Alzheimer's disease. J Neurol Sci 2005;229-230:285-92.

47. Aliev G, Cirillo R, Salvatico E, Paro M, Prosdocimi M. Changes in vessel ultrastructure during ischemia and reperfusion of rabbit hindlimb: implications for therapeutic intervention. Microvasc Res 1993;46:65-76. [PubMed: 8412853]

48. Salvatico E, Aliev GM, Novello D, Prosdocimi M. Functional depression of isolated perfused rat heart mediated by activated leukocytes: protective effect of cloricromene. J Cardiovasc Pharmacol 1994;24:638-47. [PubMed: 7528847]

49. Al-Abdulla NA, Martin LJ. Apoptosis of retrogradely degenerating neurons occurs in association with the accumulation of perikaryal mitochondria and oxidative damage to the nucleus. Am J Pathol 1998;153:447-56. [PubMed: 9708805]

50. Hirai K, Aliev G, Nunomura A, Fujioka H, Russell RL, Atwood CS, Johnson AB, Kress Y, Vinters HV, Tabaton M, Shimohama S, Cash AD, Siedlak SL, Harris PL, Jones PK, Petersen RB, Perry G, Smith MA. Mitochondrial abnormalities in Alzheimer's disease. J Neurosci 2001;21:3017-23. [PubMed: 11312286]

51. Maxwell AJ. Mechanisms of dysfunction of the nitric oxide pathway in vascular diseases. Nitric Oxide 2002;6:101-24. [PubMed: 11890735]

52. Naseem KM. The role of nitric oxide in cardiovascular diseases. Mol Aspects Med 2005;26:33-65. [PubMed: 15722114]

53. Garthwaite J, Beaumont PS. Excitatory amino acid receptors in the parallel fibre pathway in rat cerebellar slices. Neurosci Lett 1989;107:151-6. [PubMed: 2575725] 
54. Iadecola C, Li J, Ebner TJ, Xu X. Nitric oxide contributes to functional hyperemia in cerebellar cortex. Am J Physiol 1995;268:R1153-62. [PubMed: 7539595]

55. Iadecola C, Zhang F, Xu S, Casey R, Ross ME. Inducible nitric oxide synthase gene expression in brain following cerebral ischemia. J Cereb Blood Flow Metab 1995;15:378-84. [PubMed: 7536197]

56. Iadecola C, Zhang F, Casey R, Clark HB, Ross ME. Inducible nitric oxide synthase gene expression in vascular cells after transient focal cerebral ischemia. Stroke 1996;27:1373-80. [PubMed: 8711805]

57. Bredt DS, Snyder SH. Nitric oxide: a physiologic messenger molecule. Annu Rev Biochem 1994;63:175-95. [PubMed: 7526779]

58. Beckman JS, Koppenol WH. Nitric oxide, superoxide, and peroxynitrite: the good, the bad, and ugly. Am J Physiol 1996;271:C1424-37. [PubMed: 8944624]

59. Luth HJ, Holzer M, Gartner U, Staufenbiel M, Arendt T. Expression of endothelial and inducible NOS-isoforms is increased in Alzheimer's disease, in APP23 transgenic mice and after experimental brain lesion in rat: evidence for an induction by amyloid pathology. Brain Res 2001;913:57-67. [PubMed: 11532247]

60. Luth HJ, Munch G, Arendt T. Aberrant expression of NOS isoforms in Alzheimer's disease is structurally related to nitrotyrosine formation. Brain Res 2002;953:135-43. [PubMed: 12384247]

61. Williamson KS, Gabbita SP, Mou S, West M, Pye QN, Markesbery WR, Cooney RV, Grammas P, Reimann-Philipp U, Floyd RA, Hensley K. The nitration product 5-nitro-gamma-tocopherol is increased in the Alzheimer brain. Nitric Oxide 2002;6:221-7. [PubMed: 11890747]

62. Bogumil R, Knipp M, Fundel SM, Vasak M. Characterization of dimethylargininase from bovine brain: evidence for a zinc binding site. Biochemistry 1998;37:4791-8. [PubMed: 9537995]

63. Kimoto M, Whitley GS, Tsuji H, Ogawa T. Detection of NG, NG-dimethylarginine dimethylaminohydrolase in human tissues using a monoclonal antibody. J Biochem (Tokyo) 1995;117:237-8. [PubMed: 7608105]

64. MacAllister RJ, Parry H, Kimoto M, Ogawa T, Russell RJ, Hodson H, Whitley GS, Vallance P. Regulation of nitric oxide synthesis by dimethylarginine dimethylaminohydrolase. Br J Pharmacol 1996;119:1533-40. [PubMed: 8982498]

65. Smith MA, Vasak M, Knipp M, Castellani RJ, Perry G. Dimethylargininase, a nitric oxide regulatory protein, in Alzheimer disease. Free Radic Biol Med 1998;25:898-902. [PubMed: 9840734]

66. Selley ML. Increased concentrations of homocysteine and asymmetric dimethylarginine and decreased concentrations of nitric oxide in the plasma of patients with Alzheimer's disease. Neurobiol Aging 2003;24:903-7. [PubMed: 12928048]

67. Abe T, Tohgi H, Murata T, Isobe C, Sato C. Reduction in asymmetrical dimethylarginine, an endogenous nitric oxide synthase inhibitor, in the cerebrospinal fluid during aging and in patients with Alzheimer's disease. Neurosci Lett 2001;312:177-9. [PubMed: 11602339]

68. Haas J, Storch-Hagenlocher B, Biessmann A, Wildemann B. Inducible nitric oxide synthase and argininosuccinate synthetase: co-induction in brain tissue of patients with Alzheimer's dementia and following stimulation with beta-amyloid 1-42 in vitro. Neurosci Lett 2002;322:121-5. [PubMed: 11958858]

69. Heneka MT, Wiesinger H, Dumitrescu-Ozimek L, Riederer P, Feinstein DL, Klockgether T. Neuronal and glial coexpression of argininosuccinate synthetase and inducible nitric oxide synthase in Alzheimer disease. J Neuropathol Exp Neurol 2001;60:906-16. [PubMed: 11556547]

70. Barford PA, Blair JA, Eggar C, Hamon C, Morar C, Whitburn SB. Tetrahydrobiopterin metabolism in the temporal lobe of patients dying with senile dementia of Alzheimer type. J Neurol Neurosurg Psychiatry 1984;47:736-8. [PubMed: 6747650]

71. Aziz AA, Leeming RJ, Blair JA. Tetrahydrobiopterin metabolism in senile dementia of Alzheimer type. J Neurol Neurosurg Psychiatry 1983;46:410-3. [PubMed: 6152915]

72. Stroes E, Hijmering M, van Zandvoort M, Wever R, Rabelink TJ, van Faassen EE. Origin of superoxide production by endothelial nitric oxide synthase. FEBS Lett 1998;438:161-4. [PubMed: 9827538]

73. Luth HJ, Holzer M, Gertz HJ, Arendt T. Aberrant expression of nNOS in pyramidal neurons in Alzheimer's disease is highly co-localized with p21ras and p16INK4a. Brain Res 2000;852:45-55. [PubMed: 10661494] 
74. Salvemini D, Marino MH. Inducible nitric oxide synthase and inflammation. Expert Opin Investig Drugs 1998;7:65-75.

75. Ignarro LJ. Biosynthesis and metabolism of endothelium-derived nitric oxide. Annu Rev Pharmacol Toxicol 1990;30:535-60. [PubMed: 2188578]

76. Wong A, Luth HJ, Deuther-Conrad W, Dukic-Stefanovic S, Gasic-Milenkovic J, Arendt T, Munch G. Advanced glycation endproducts co-localize with inducible nitric oxide synthase in Alzheimer's disease. Brain Res 2001;920:32-40. [PubMed: 11716809]

77. Fernandez-Vizarra P, Fernandez AP, Castro-Blanco S, Encinas JM, Serrano J, Bentura ML, Munoz P, Martinez-Murillo R, Rodrigo J. Expression of nitric oxide system in clinically evaluated cases of Alzheimer's disease. Neurobiol Dis 2004;15:287-305. [PubMed: 15006699]

78. Lee SC, Zhao ML, Hirano A, Dickson DW. Inducible nitric oxide synthase immunoreactivity in the Alzheimer disease hippocampus: association with Hirano bodies, neurofibrillary tangles, and senile plaques. J Neuropathol Exp Neurol 1999;58:1163-9. [PubMed: 10560659]

79. Nathan C, Calingasan N, Nezezon J, Ding A, Lucia MS, La Perle K, Fuortes M, Lin M, Ehrt S, Kwon NS, Chen J, Vodovotz Y, Kipiani K, Beal MF. Protection from Alzheimer's-like disease in the mouse by genetic ablation of inducible nitric oxide synthase. J Exp Med 2005;202:1163-9. [PubMed: 16260491]

80. de la Torre JC. Alzheimer disease as a vascular disorder: nosological evidence. Stroke 2002;33:115262. [PubMed: 11935076]

81. Colton CA, Brown CM, Cook D, Needham LK, Xu Q, Czapiga M, Saunders AM, Schmechel DE, Rasheed K, Vitek MP. APOE and the regulation of microglial nitric oxide production: a link between genetic risk and oxidative stress. Neurobiol Aging 2002;23:777-85. [PubMed: 12392781]

82. Brown CM, Wright E, Colton CA, Sullivan PM, Laskowitz DT, Vitek MP. Apolipoprotein E isoform mediated regulation of nitric oxide release. Free Radic Biol Med 2002;32:1071-5. [PubMed: 12031891]

83. Colton CA, Needham LK, Brown C, Cook D, Rasheed K, Burke JR, Strittmatter WJ, Schmechel DE, Vitek MP. APOE genotype-specific differences in human and mouse macrophage nitric oxide production. J Neuroimmunol 2004;147:62-7. [PubMed: 14741429]

84. Chibber R, Molinatti PA, Rosatto N, Lambourne B, Kohner EM. Toxic action of advanced glycation end products on cultured retinal capillary pericytes and endothelial cells: relevance to diabetic retinopathy. Diabetologia 1997;40:156-64. [PubMed: 9049475]

85. Graier WF, Posch K, Wascher TC, Kostner GM. Role of superoxide anions in changes of endothelial vasoactive response during acute hyperglycemia. Horm Metab Res 1997;29:622-6. [PubMed: 9497899]

86. Pieper GM, Jordan M, Dondlinger LA, Adams MB, Roza AM. Peroxidative stress in diabetic blood vessels. Reversal by pancreatic islet transplantation. Diabetes 1995;44:884-9. [PubMed: 7621992]

87. Lang D, Kredan MB, Moat SJ, Hussain SA, Powell CA, Bellamy MF, Powers HJ, Lewis MJ. Homocysteine-induced inhibition of endothelium-dependent relaxation in rabbit aorta: role for superoxide anions. Arterioscler Thromb Vasc Biol 2000;20:422-7. [PubMed: 10669639]

88. Shimohama S, Tanino H, Kawakami N, Okamura N, Kodama H, Yamaguchi T, Hayakawa T, Nunomura A, Chiba S, Perry G, Smith MA, Fujimoto S. Activation of NADPH oxidase in Alzheimer's disease brains. Biochem Biophys Res Commun 2000;273:5-9. [PubMed: 10873554]

89. Perry G, Epel D. Fertilization stimulates lipid peroxidation in the sea urchin egg. Dev Biol 1985;107:58-65. [PubMed: 3917416]

90. Perry G, Epel D. Characterization of a Ca2+-stimulated lipid peroxidizing system in the sea urchin egg. Dev Biol 1985;107:47-57. [PubMed: 3917415]

91. Zhu X, Smith MA, Perry G, Aliev G. Mitochondrial failures in Alzheimer's disease. Am J Alzheimers Dis Other Demen 2004;19:345-52. [PubMed: 15633943]

92. Rodriguez G, Vitali P, Canfora M, Calvini P, Girtler N, De Leo C, Piccardo A, Nobili F. Quantitative EEG and perfusional single photon emission computed tomography correlation during long-term donepezil therapy in Alzheimer's disease. Clin Neurophysiol 2004;115:39-49. [PubMed: 14706467]

93. Rodriguez G, Vitali P, Calvini P, Bordoni C, Girtler N, Taddei G, Mariani G, Nobili F. Hippocampal perfusion in mild Alzheimer's disease. Psychiatry Res 2000;100:65-74. [PubMed: 11114492] 
94. Okamura N, Shinkawa M, Arai H, Matsui T, Nakajo K, Maruyama M, Hu XS, Sasaki H. [Prediction of progression in patients with mild cognitive impairment using IMP-SPECT]. Nippon Ronen Igakkai Zasshi 2000;37:974-8. [PubMed: 11201187]

95. Kogure D, Matsuda H, Ohnishi T, Asada T, Uno M, Kunihiro T, Nakano S, Takasaki M. Longitudinal evaluation of early Alzheimer's disease using brain perfusion SPECT. J Nucl Med 2000;41:115562. [PubMed: 10914904]

96. Johnson KA, Jones K, Holman BL, Becker JA, Spiers PA, Satlin A, Albert MS. Preclinical prediction of Alzheimer's disease using SPECT. Neurology 1998;50:1563-71. [PubMed: 9633695]

97. Johnson KA, Albert MS. Perfusion abnormalities in prodromal AD. Neurobiol Aging 2000;21:28992. [PubMed: 10867213]

98. Niwa K, Kazama K, Younkin L, Younkin SG, Carlson GA, Iadecola C. Cerebrovascular autoregulation is profoundly impaired in mice overexpressing amyloid precursor protein. Am J Physiol Heart Circ Physiol 2002;283:H315-23. [PubMed: 12063304]

99. de la Torre JC. Critically attained threshold of cerebral hypoperfusion: the CATCH hypothesis of Alzheimer's pathogenesis. Neurobiol Aging 2000;21:331-42. [PubMed: 10867218]

100. Lipton P. Ischemic cell death in brain neurons. Physiol Rev 1999;79:1431-568. [PubMed: 10508238]

101. Sekhon LH, Morgan MK, Spence I, Weber NC. Chronic cerebral hypoperfusion: pathological and behavioral consequences. Neurosurgery 1997;40:548-56. [PubMed: 9055295]

\section{Abbreviations}

AGE

advanced glycation end products

AD

Alzheimer disease

$\mathbf{A \beta}$

amyloid- $\beta$

AßPP

amyloid- $\beta$ protein precursor

ApoE

apolipoprotein E

BBB

blood brain barrier

CBF

cerebral blood flow

CSF

cerebrospinal fluid

CATCH

a critically attained threshold of cerebral hypoperfusion

$\operatorname{cox}$

cytochrome $\mathrm{C}$ oxidase subunit 1

8OHG

8-hydroxy-2 $\beta$-guanosine

8OHdG

8-hydroxy-deoxyguanosine 
MCI

mild cognitive impairment

mtDNA

mitochondrial DNA

NFT

neurofibrillary tangles

NO

nitric oxide

PUFA

polyunsaturated fatty acids

ROS

reactive oxygen species

SOD

superoxide dismutase 